\title{
An Online Database of Sweetpotato Germplasm Collection in Uganda
}

\author{
Benard Yada and Phinehas Tukamuhabwa \\ Department of Crop Science, Makerere University, P.O. Box 7062, Kampala, \\ Uganda
}

\author{
Arthur Villordon \\ LSU AgCenter, Sweet Potato Research Station, 130 Sweet Potato Road, \\ Chase, LA 71324
}

\author{
Agnes Alajo and Robert O.M. Mwanga ${ }^{1,2}$ \\ National Agricultural Research Organization (NARO), National Crops \\ Resources Research Institute (NaCRRI), Namulonge, P.O. Box 7084, \\ Kampala, Uganda
}

Additional index words. Ipomoea batatas, genetic erosion, passport data, landrace, genetic diversity

Sweetpotato [Ipomoea batatas (L.) Lam], the world's seventh most important crop, is widely grown and consumed as a staple food crop in Uganda. Uganda is the third largest global producer after China and Nigeria (Food and Agricultural Organization, 2007). It lies within the East African region, which is considered a secondary center of diversity for the crop where the farmers grow and maintain large numbers of different cultivars and landraces (Mwanga et al., 2001; Villordon et al., 2006). Genetic erosion threatens this diversity as a result of sweetpotato virus disease (SPVD) caused by dual infection of Sweetpotato feathery mottle virus (Potyvirus; Potyviridae) and Sweetpotato chlorotic stunt virus (Crinivirus; Closteroviridae) (Gibson et al., 1998), Alternaria bataticola blight, and African sweetpotato weevils, Cylas puncticollis Boheman and Cylas brunneus Fabricius. Farmers are also known to abandon poor-performing traditional cultivars in favor of newly developed ones released by the national breeding program (Bashaasha et al., 1995; Mwanga et al., 2001).

The National Sweetpotato Program based at the National Crops Resources Research Institute (NaCRRI), Namulonge, Uganda, undertook a rigorous germplasm collection, characterization, evaluation, and conservation program to mitigate sweetpotato genetic erosion and also to find superior germplasm for cultivar development in hybridization schemes. A total of 1303 accessions of sweet-

Received for publication 28 July 2009. Accepted for publication 27 Oct. 2009.

We thank the McKnight Foundation for funding this research.

${ }^{1}$ Former Team Leader, Sweetpotato Research, NARO; currently sweetpotato breeder, Sub-Saharan Africa, International Potato Center (CIP), Naguru Hill, Katalima Road, Plot 106, Box 2274, Kampala, Uganda.

${ }^{2}$ To whom reprint requests should be addressed; e-mail r.mwanga@cgiar.org. potato germplasm were collected from 21 major sweetpotato-producing districts of Uganda from January to July 2005. Information about farmers' indigenous knowledge of the cultivars was also collected. These accessions were assembled at NaCRRI and morphologically characterized using 40 standard root, vine, leaf, and flower descriptors of sweetpotato [International Potato Center (CIP), Asian Vegetable Research and Development Center, and International Board for Plant Genetic Resources, 1991] scored 90 to $100 \mathrm{~d}$ after planting in the field. A total of 946 morphologically distinct accessions were identified after removal of duplicates. Field evaluations were also conducted for SPVD, Alternaria blight, and yield at three sites for two seasons. Subsequently, 192 superior genotypes were selected from the germplasm evaluation of which 190 were genetically distinct on molecular characterization using 10 fluorescent-labeled simple sequence repeat markers, IB-R16 (VIC), IB-R19 (PET), IBCIP-13 (NED), IB-R03 (PET), IBCIP-9 (6-FAM), IB-S09 (NED), IB-R08 (PET), IB-R12 (NED), IB-S07 (6-FAM), and IB-S07 (PET), obtained from CIP, Lima, Peru. The database for sweetpotato germplasm collection in Uganda referred to as the "Uganda Sweetpotato Germplasm Database" (USGDB) is described.

To our knowledge, the USGDB is the most comprehensive description of collected sweetpotato germplasm in the region. USGDB has all 946 morphologically distinct accessions fully described, including passport (accession identifiers and information recorded by collectors) data, morphological characterization, and evaluation data. This database has been made available online for public use at: http:// www.viazivitamu.org/ugasp_db/index.php. The database contains the names, accession number as assigned by collectors, geographical location (longitude and latitude), form of maintenance, and a total of 40 morphological descriptors. It further contains the total root yield, SPVD, and Alternaria bataticola blight disease resistance values for each accession. This online database is an important resource for enhancing the global exchange of sweetpotato germplasm. An online web-accessible database developed for the sweetpotato germplasm collection in Kenya called the "Viazivitamu database" is also available at http:// www.viazivitamu.org (Villordon et al., 2007). The Ugandan and Kenyan databases will eventually be merged and expanded to produce a comprehensive regional database of sweetpotato germplasm resources that is representative of the entire East African region after checking for duplicates in the two collections.

This USGDB collection is being maintained in the screenhouse and field at NaCRRI. Some 30 accessions are being maintained in vitro at the CIP gene bank at Lima, Peru. Request for this germplasm should be directed to the National Sweetpotato Program, NaCRRI, P.O. Box 7084, Kampala, Uganda.

\section{Literature Cited}

Bashaasha, B., R.O.M. Mwanga, C.O. p'Obwoya, and P.T. Ewell. 1995. Sweetpotato in the farming and food systems of Uganda: A farm survey report. International Potato Center, SubSaharan Africa Region, Nairobi, Kenya.

Food and Agricultural Organization. 2007. FAOSTAT on-line database. June 2009. <http:/ faostat.fao.org/>.

Gibson, R.W., I. Mpembe, T. Alicai, E.E. Carey, R.O.M. Mwanga, S.E. Seal, and H.F. Vatten. 1998. Symptoms, etiology and serological analysis of sweetpotato virus disease in Uganda. Plant Pathol. 47:95-102.

International Potato Center, Asian Vegetable Research and Development Center, and the International Board for Plant Genetic Resources. 1991. Descriptors for sweetpotato. In: Huaman, Z. (ed.). Intl. Board for Plant Genetic Resources, Rome, Italy.

Mwanga, R.O.M., B. Odongo, C. Ocitti p'Obwoya, R.W. Gibson, N.E.J.M. Smit, and E.E. Carey. 2001. Release of five sweetpotato cultivars in Uganda. HortScience 36:385-386.

Villordon, A., W. Njuguna, S. Gichuki, P. Ndolo, H. Kulembeka, S.C. Jeremiah, D. Labonte, B. Yada, P. Tukamuhabwa, and R.O.M. Mwanga. 2006. Using GIS-based tools and distribution modeling to determine sweetpotato germplasm exploration and documentation priorities in Sub-Saharan Africa. HortScience 41:13771381 .

Villordon, A., W. Njuguna, S. Gichuki, P. Ndolo, and D. Labonte. 2007. Using open source software in developing a web-accessible database of sweetpotato germplasm in Kenya. HortTechnology 17:567-570. 